ISSN: 1410-8917

Jurnal Kimia Sains \& Aplikasi

e-ISSN: 2597-9914

\section{Jurnal Kimia Sains dan Aplikasi} Journal of Scientific and Applied Chemistry

Journal homepage: http://ejournal.undip.ac.id/index.php/ksa

\title{
Effect of Lactose Concentration as Lactobacillus bulgaricus Substrate on Potential Cells Produced in Microbial Fuel Cell Systems
}

\author{
Riska Anggri Kusuma ${ }^{a}$, W. H. Rahmanto ${ }^{a}$, Linda Suyati ${ }^{{ }^{*}}$ \\ a Chemistry Department, Faculty of Sciences and Mathematics, Diponegoro University, Jalan Prof. Soedarto, Tembalang, Semarang \\ *Corresponding author: linda_suyati@live.undip.ac.id
}

https://doi.org/10.14710/jksa.21.3.144-148

\begin{tabular}{l} 
Article Info \\
\hline Article history: \\
Received: 1 July 2018 \\
Revised: 25 July 2018 \\
Accepted: 26 July 2018 \\
Online: 31 July 2018
\end{tabular}

Keywords:

Cell Potential,

Lactobacillus bulgaricus,

Lactose, MFC

\begin{abstract}
The effect of laxose concentration as Lactobacillus bulgaricus bacterial substrate on the cell potential produced in Microbial Fuel Cell System has been done. This study aims to determine the effect of lactose concentration as bacterial substrate, to generate electricity, maximum electric potential and determine the potential value of standard lactose ( $\mathrm{E}_{\text {Lactose }}^{\circ}$ ) Based on Nernst equation. The MFC system of two compartments and bridges of salt as a linkage is used in this study. Anode contains lactose with variation of concentration $3-7 \%$ and bacteria. The cathode contains a $1 \mathrm{M} \mathrm{KMO}$. The electrodes used are graphite. MFC operational time is 14 days. The results showed that the lactose concentration had an effect on the cell potential produced in the MFC system. Maximum cell potential yielded at $4 \%$ lactose concentration, that is $710 \mathrm{mV}$ then based on Nerst

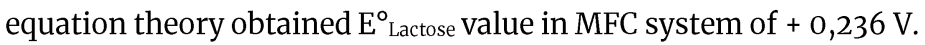

\section{Abstrak}

Kata Kunci:

Lactobacillus bulgaricus, Laktosa, MFC, Potensial sel
Pengaruh konsentrasi laksosa sebagai substrat bakteri Lactobacillus bulgaricus terhadap potensial sel yang dihasilkan pada Sistem Microbial Fuel Cell telah dilakukan. Penelitian ini bertujuan menentukan pengaruh konsentrasi laktosa sebagai substrat bakteri,untuk menghasilkan listrik, potensial listrik maksimum dan menentukan nilai potensial standar laktosa ( $\mathrm{E}_{\text {Laktosa }}^{\mathrm{o}}$ ) berdasarkan persamaan Nernst. System MFC dua kompartemen dan jembatan garam sebagai penghubungnya.digunakan dalam penelitian ini. Anoda berisi laktosa dengan variasi konsentrasi $3-7 \%$ dan bakteri. Katoda berisi $\mathrm{KMO}_{4} 1 \mathrm{M}$. Elektroda yang dipakai adalah grafit. Waktu operasional MFC adalah 14 hari. Hasil penelitian menunjukkan bahwa konsentrasi laktosa berpengaruh terhadap potensial sel yang dihasilkan pada sistem MFC. Potensial sel maksimum yang dihasilkan pada konsentrasi laktosa 4\%, yaitu sebesar $710 \mathrm{mV}$ kemudian berdasarkan

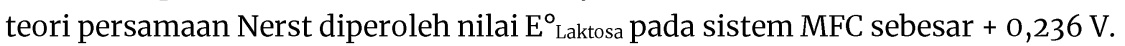

\section{Introduction}

Pada era teknologi yang serba canggih seperti saat ini, listrik sudah menjadi kebutuhan bagi manusia. Banyak perangkat elektronik yang diciptakan semuanya membutuhkan energi listrik. Sumber energi listrik yang digunakan untuk perangkat-perangkat elektronik tersebut, ada yang berbahan bakar berasal dari alam seperti minyak bumi, air, panas bumi dan ada juga sumber energi listrik yang berasal dari senyawa kimia, seperti baterai. Namun semua bahan bakar listrik tersebut disamping menguntungkan bagi manusia, juga dapat merugikan, sebagai contoh berdampak pada polusi, 
dan keterbatasan bahan bakar itu sendiri. Maka dari itu, banyak peneliti melakukan penelitian untuk mencari solusi dalam menciptakan sumber energi listrik yang ramah lingkungan seperti biogas dan fuel cell. Fuel cell merupakan baterai berbahan bakar hidrogen yang mengkonversi energi kimia menjadi energi listrik. Salah satu jenis fuel cell yang sedang dikembangkan saat ini adalah Microbial Fuel Cell.

Microbial Fuel Cell (MFC) merupakan suatu sistem yang mengubah energi kimia dalam bentuk campuran organik menjadi energi listrik, dengan bantuan mikroba. Mikroba tersebut dapat mendegradasi medium organik sehingga menghasilkan elektron dan proton dari proses reaksi reduksi dan oksidasi. Elektron inilah yang dapat menghasilkan energi listrik [1]. Energi listrik yang dihasilkan dari sistem Microbial Fuel Cell (MFC) sangat dipengaruhi oleh banyak faktor seperti agitasi, rangkaian pada sistem MFC, konsentrasi substrat dan lain-lain.

Inayati $d k k$. [2] menyatakan bahwa agitasi pada kompartemen anoda dalam sistem MFC dengan menggunakan substrat laktosa dan bakteri Lactobacillus bulgaricus, hasilnya dapat meningkatkan potensial sel. Hayati $d k k$. [3] telah meneliti pengaruh rangkaian seri sistem MFC menggunakan bakteri Lactobacillus bulgaricus dengan substrat laktosa. Hasil yang diperoleh dengan adanya rangkaian seri dapat meningkatkan potensial sel. Selain itu, Rohan $d k k$. [4] melakukan penelitian tentang variasi konsentrasi glukosa 4-6\% dengan bakteri Escherichia coli. Hasil yang diperoleh adalah potensial sel maksimal dihasilkan pada konsentrasi glukosa 5\%.

Berdasarkan uraian tersebut di atas, maka pada penelitian ini akan mengkaji lebih dalam dari sisi konsentrasi substrat laktosa $3-7 \%$ dengan bakteri Lactobacillus bulgaricus. Selain itu pada teori persamaan Nernst menjelaskan bahwa potensial sel dipengaruhi oleh konsentrasi, oleh karena itu untuk menentukan nilai

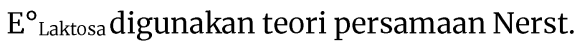

\section{Metode Penelitian}

\section{Bahan}

Bahan-bahan yang digunakan dalam penelitian ini adalah bakteri Lactobacillus bulgaricus, laktosa, $\mathrm{KMnO}_{4}$, MRS (Media deMan Rogosa and Sharpe) broth, Media NA, agar-agar, alkohol, $\mathrm{HCl}, \mathrm{KCl}$, buffer fosfat $\mathrm{pH}=7, \mathrm{NaOH}$, dan reagen Benedict.

\section{Alat}

Peralatan yang digunakan dalam penelitian ini meliputi autoklaf, anoda dan katoda karbon, erlenmeyer, gelas beker, gelas ukur, hotplate dan stirrer, inkubator, labu ukur, lampu LED, multimeter SANWA CD800a, mikro pipet, neraca analitik KERN ALS 220-4N, pipa U, reaktor MFC, resistor $1,1 \Omega$, spektrofotometer UV-Vis PG Instruments Limited Model T60U, termometer, tabung reaksi, kabel dan jarum ose.

\section{Preparasi bakteri Lactobacillus bulgaricus}

Bibit bakteri Lactobacillus bulgaricus murni dimasukkan ke dalam medium MRS broth dalam kondisi steril dan diinkubasi selama 48 jam pada suhu $37^{\circ} \mathrm{C}$. Selanjutnya bakteri ini sebagai starter untuk dimasukkan dalam laktosa dengan konsentrasi konsentrasi 3, 4, 5, 6 dan $7 \%$ dan diinkubasi pula selama 48 jam pada suhu 37 ${ }^{\circ} \mathrm{C}$.

\section{Kontruksi MFC}

Rangkaian MFC terdiri dari dua kompartemen (anoda dan katoda) yang mempunyai volume 100mL.Kedua kompartemen dihubungkan jembatan garam yang terbuat dari 5 gram agar-agar dan larutan KCL 1M. Pada kompartemen anoda diisi bakteri yang telah dibiakkan sebanyak $20 \mathrm{~mL}$, ditambahkan laktosa sebanyak $60 \mathrm{~mL}$ dan larutan buffer fosfat $20 \mathrm{~mL}$

\section{Pengukuran potensial sel dan arus}

Pengukuran potensial sel dan arus dilakukan menggunakan alat ukur yang disebut multimeter. Untuk mengetahui arus listrik pada MFC, maka pada salah satu kutub dipasang hambatan (resistor), sedangkan untuk mengetahui potensial sel, cukup dengan mengukur kutub anoda dan katoda pada MFC tanpa menggunakan hambatan. Pengukuran potensial dan arus dilakukan pada semua konsentrasi laktosa sampai mengalami penurunan.

\section{Uji Karbohidrat Laktosa}

Laktosa konsentrasi 3-7\% dilakukan dengan uji benedict. Lima tabung pereaksi yang berisi $5 \mathrm{~mL}$ laktosa konsentrasi 3, 4, 5, 6 dan 7\%, dan ditambahkan larutan benedict sebanyak $5 \mathrm{~mL}$ kemudian dipanaskan selama 5 menit. Pengujian larutan hasil uji benedict dilakukan pengukuran absorbansi dengan spektrofometer uv-vis.

\section{Penentuan $\mathrm{E}_{\text {Laktosa }}^{\circ}$}

Pada teori persamaan Nernst menjelaskan bahwa potensial listrik dipengaruhi oleh konsentrasi. Dari persamaan Nernst tersebut dapat digunakan untuk menentukan nilai $\mathrm{E}_{\text {Laktosa. }}^{\mathrm{o}}$

\section{Hasil dan Pembahasan}

\section{Desain Alat Microbial Fuel Cell (MFC)}

Alat MFC pada penelitian ini menggunakan sebuah kotak (inkubator) dengan panjang $60 \mathrm{~cm}$, lebar $25 \mathrm{~cm}$ dan tinggi $25 \mathrm{~cm}$. Bagian dalam inkubator terdapat 5 pasang kompartemen anoda dan katoda dengan volume masingmasing kompartemen $100 \mathrm{~mL}$. Inkubator didesain anaerob agar tidak ada oksigen yang masuk. Dalam inkubator tersebut dipasang sebuah kipas, lampu 5 watt dan termometer. Hal ini bertujuan untuk mengatur suhu optimal pertumbuhan bakteri Lactobacillus bulgaricus pada suhu $37^{\circ} \mathrm{C}[5]$.

Masing-masing kompartemen dipasang resistor terkecil yang ada dipasaran dengan hambatan sebesar 1,1 
$\Omega$ yang dihubungkan ke anoda.dengan harapan bisa menghasilkan pembacaan potensial dan arus yang sebesar besarnya. Bagian bawah penutup inkubator dipasang kabel sepanjang $20 \mathrm{~cm}$ yang akan disambungkan ke elektroda pada masing-masing kompartemen. Berikut merupakam alat MFC yang digunakan dalam penelitian (Gambar.1).

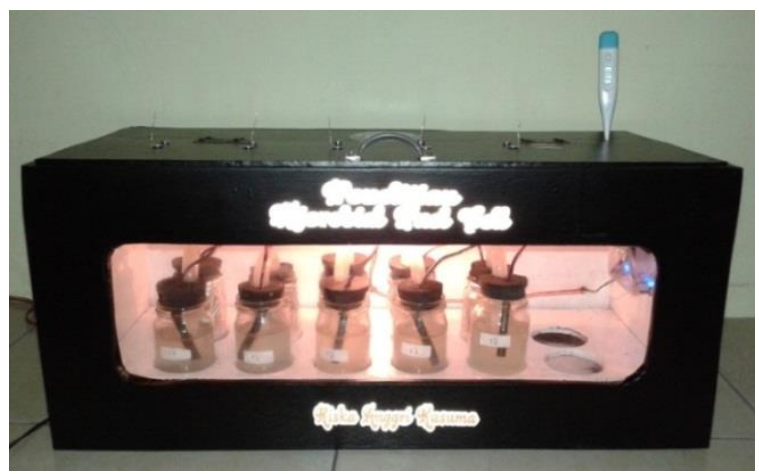

Gambar 1. Alat MFC

Elektroda yang digunakan pada setiap kompartemen adalah jenis elektroda grafit. Luas permukaan elektroda ini sebesar 14,6 $\mathrm{cm}^{2}$ dengan diameter $0,8 \mathrm{~cm}$ dan panjang $5,7 \mathrm{~cm}$. Elektroda direndam terlebih dahulu dalam $\mathrm{HCl} 1$ $M$ dan $\mathrm{NaOH} 1 \mathrm{M}$ sebelum digunakan dalam sistem MFC, dengan tujuan untuk menghilangkan pengotor. Untuk menghubungkan anoda dan katoda dipasang jembatan garam yang berisi larutan $\mathrm{KCl} 1 \mathrm{M}$ dan agar-agar. Jembatan garam berfungsi sebagai tempat proton berdifusi dari anoda ke katoda.

\section{Potensial dan Arus pada Sistem MFC}

Untuk mengetahui potensial dan arus yang dihasilkan pada sistem MFC, maka dilakukan pengukuran potensial sel dan arus listrik pada masing-masing konsentrasi laktosa. Pengukuran potensial sel dan arus listrik dilakukan selama 14 hari pada sistem MFC, hasil yang diperoleh pada konsentrasi laktosa 3-7\% seperti pada Gambar 2 dan Gambar 3.

Berdasarkan grafik pada Gambar 2, hasil potensial tertinggi pada konsentrasi laktosa 3-7\% berturut-turut adalah $652 \mathrm{mV}, 710 \mathrm{mV}, 453 \mathrm{mV}, 599 \mathrm{mV}$ dan $558 \mathrm{mV}$. Grafik pada Gambar IV.3 menunjukan hasil arus tertinggi pada konsentrasi laktosa $3-7 \%$ berturut-turut adalah 203,8 $\mu \mathrm{A}, 221,9 \mu \mathrm{A}, 144,6 \mu \mathrm{A}, 191,5 \mu \mathrm{A}$ dan 174,4 $\mu \mathrm{A}$.

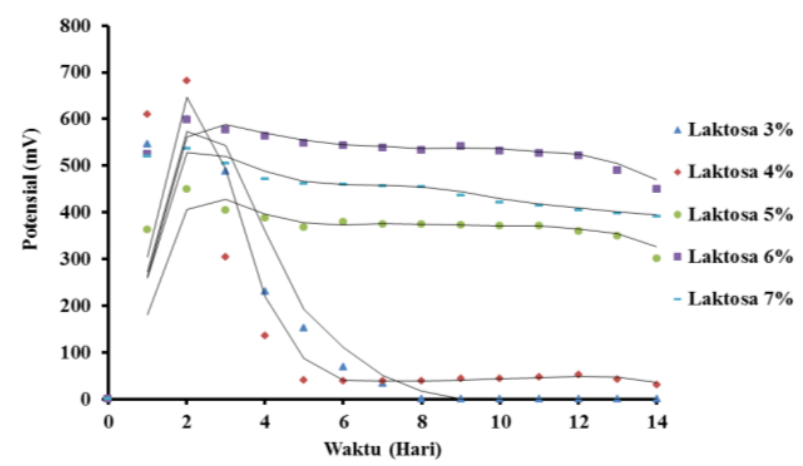

Gambar 2. Grafik pengukuran potensial sel selama 14 hari

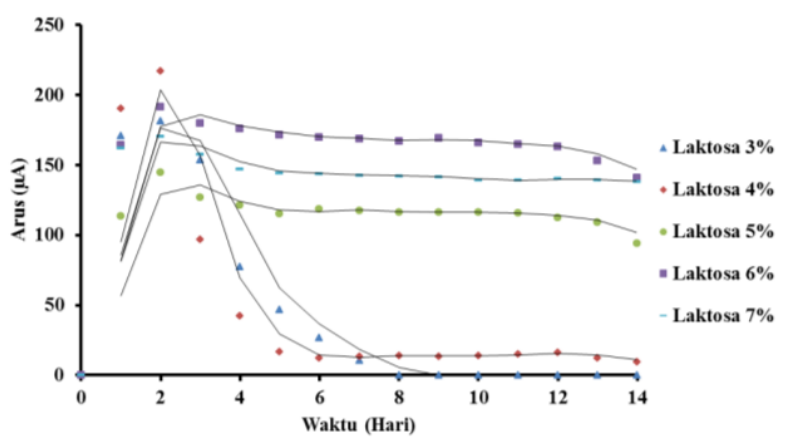

Gambar 3. Grafik pengukuran arus selama 14 hari

Pengukuran potensial dan arus dilakukan secara kontinyu selama 14 hari. Pada hari ke-2 potensial dan arus menunjukkan adanya kenaikan yang cukup signifikan. Artinya pada hari kedua bakteri sudah dapat beradaptasi dan mengalami pertumbuhan yang maksimum.

Sesuai dengan persamaan hukum omh : V = I.R, dimana $\mathrm{V}$ (potensial)yang berbanding lurus dengan I (arus) dan berbanding terbalik dengan $\mathrm{R}$ (tegangan), maka pada grafik 2 dan 3 bisa dijelaskan bahwa pada hari ke-3 sampai hari ke-14, potensial dan arus yang dihasilkan dari konsentrasi 3-4\% mengalami penurunan secara drastis. Hal ini dikarenakan jumlah laktosa pada konsentrasi $3-4 \%$ tersisa 0,01 dan $0,02 \%$ sehingga makanan bakteri sedikit, arus dan potensial yang dihasilkan juga lebih sedikit. Jumlah laktosa pada konsentrasi 5-7\% masih tersedia sampai hari ke-14 yaitu 0,37; 0,62 dan 1,66\%., sehingga jumlah makanan bakteri cukup untuk degradasi sampai pada hari ke- 14 dan potensial serta arus yang dihasilkan juga akan bertahan lebih lama . Reaksi yang terjadi adalah sebagai berikut.

Anoda:

$\mathrm{C}_{12} \mathrm{H}_{22} \mathrm{O}_{11}+13 \mathrm{H}_{2} \mathrm{O} \rightarrow 12 \mathrm{CO}_{2}+48 \mathrm{H}^{+}+48 \mathrm{e}^{-}$

Katoda:

$12 \mathrm{O}_{2}+48 \mathrm{H}^{+}+48 \mathrm{e}^{-} \rightarrow 24 \mathrm{H}_{2} \mathrm{OE}^{\circ}=1,23 \mathrm{~V}$

Reaksi secara keseluruhan

$\mathrm{C}_{12} \mathrm{H}_{22} \mathrm{O}_{11}+12 \mathrm{O}_{2} \rightarrow 12 \mathrm{CO}_{2}+11 \mathrm{H}_{2} \mathrm{O}$

Dari reaksi tersebut dapat ditinjau hubungan konsentrasi dengan potensial sel yang dihasilkan pada sistem MFC dengan menggunakan persamaan Nernst sebagai berikut:

$$
\begin{gathered}
\mathrm{E}=\mathrm{E}^{\circ}-\frac{\mathrm{RT}}{\mathrm{nF}} \ln \mathrm{Q} \\
\mathrm{E}=\mathrm{E}^{\circ}-\frac{\mathrm{RT}}{\mathrm{nF}} \ln \frac{\mathrm{a}_{\mathrm{p}}}{\mathrm{a}_{\mathrm{r}}} \\
\mathrm{E}=\mathrm{E}^{\circ}-\frac{\mathrm{RT}}{\mathrm{nF}} \ln \frac{\left[\mathrm{f}_{\mathrm{CO}_{2}}\right]^{12} \times\left[\mathrm{a}_{\mathrm{H}_{2} \mathrm{O}}\right]^{11}}{\left[\mathrm{a}_{\left.\mathrm{C}_{12} \mathrm{H}_{22} \mathrm{O}_{11}\right]^{1} \times\left[\mathrm{f}_{\mathrm{O}_{2}}\right]^{12}}\right.}
\end{gathered}
$$




$$
\begin{gathered}
\mathrm{E}=\mathrm{E}^{\circ}-\frac{\mathrm{RT}}{\mathrm{nF}} \ln \frac{[1]^{12} \times[1]^{11}}{\left(\gamma_{\mathrm{C}_{12} \mathrm{H}_{22} \mathrm{O}_{11}} \cdot \mathrm{C}_{\mathrm{C}_{12} \mathrm{H}_{22} \mathrm{O}_{11}}\right) \times[1]^{12}} \\
\mathrm{E}=\mathrm{E}^{\circ}-\frac{\mathrm{RT}}{\mathrm{nF}} \ln \frac{1}{\gamma_{\mathrm{C}_{12} \mathrm{H}_{22} \mathrm{O}_{11}} \cdot\left[\mathrm{C}_{12} \mathrm{H}_{22} \mathrm{O}_{11}\right]} \\
\mathrm{E}=\mathrm{E}^{\circ}-\frac{\mathrm{RT}}{48 \mathrm{~F}} \ln \frac{1}{\gamma_{\mathrm{C}_{12} \mathrm{H}_{22} \mathrm{O}_{11}} \cdot\left[\mathrm{C}_{12} \mathrm{H}_{22} \mathrm{O}_{11}\right]} \\
\mathrm{E}=\mathrm{E}^{\circ}-\frac{\mathrm{RT}}{48 \mathrm{~F}} \ln \frac{1}{\left[\mathrm{C}_{12} \mathrm{H}_{22} \mathrm{O}_{11}\right]}
\end{gathered}
$$

Di mana: $\mathrm{f}=$ fugasitas, $\mathrm{a}=$ aktifitas, $\mathrm{r}=$ koefisien aktifitas

Dari persamaan Nernst tersebut menunjukan bahwa semakin tinggi konsentrasi maka akan semakin tinggi potensial sel yang akan dihasilkan. Akan tetapi potensial sel tertinggi dihasilkan pada konsentrasi laktosa 4\%. Hal ini dikarenakan potensial sel yang dihasilkan dari sistem MFC juga dipengaruhi oleh jumlah dan metabolisme bakteri [6]. Jumlah dan metabolisme bakteri mempengaruhi nilai dari $\mathrm{a}_{\mathrm{C}_{12} \mathrm{H}_{22} \mathrm{O}_{11}}$ (aktifitas laktosa). Aktifitas laktosa sebanding dengan aktifitas bakteri yang ada pada sistem MFC. Aktifitas bakteri pada konsentrasi laktosa $4 \%$ dalam keadaan maksimal sehingga potensial maksimum dihasilkan pada konsentrasi laktosa $4 \%$.

Selain itu, dalam volume reaktor yang sama, semakin banyak jumlah bakteri dapat menyebabkan kerapatan bakteri meningkat [7]. Kerapatan yang tinggi akan mengakibatkan elektron hasil metabolisme bakteri semakin sulit untuk mendekati elektroda, sehingga potensial sel yang dihasilkan juga akan lebih kecil. Hubungan antara jumlah bakteri, konsentrasi laktosa dan potensial sel ditampilkan pada Tabel 1.

Tabel 1. Hubungan jumlah bakteri, konsentrasi laktosa dan potensial sel setelah 14 hari

\begin{tabular}{cccc}
\hline $\begin{array}{c}\text { Konsentrasi } \\
\text { Laktosa } \\
\text { sebelum } \\
\text { proses } \\
\text { MFC\% }\end{array}$ & $\begin{array}{c}\text { Jumlah } \\
\text { Bakteri } \\
\text { Koloni/ } \\
\text { mL) }\end{array}$ & $\begin{array}{c}\text { Konsentrasi } \\
\text { setelah } \\
\text { proses MFC } \\
\text { Laktosa }(\%)\end{array}$ & $\begin{array}{c}\text { Potensial } \\
\text { sel }(\mathrm{mV})\end{array}$ \\
\hline 3 & $100 \times 10^{15}$ & 0.01 & 652 \\
4 & $102 \times 10^{15}$ & 0.02 & 710 \\
5 & $124 \times 10^{15}$ & 0.37 & 453 \\
6 & $128 \times 10^{15}$ & 0.62 & 499 \\
7 & $154 \times 10^{15}$ & 1.66 & 558 \\
\hline
\end{tabular}

Dari hasil tersebut menunjukan bahwa potensial sel maksimum dihasilkan pada konsentrasi laktosa $4 \%$, hal ini dimungkinkan jumlah bakteri dalam keadaan optimal, sehingga elektron yang dihasilkan akan lebih mudah melakukan kontak dengan elektroda. Pada konsentrasi 5, 6 dan 7\%, jumlah bakteri yang ada lebih banyak dibandingkan dengan jumlah bakteri pada konsentrasi laktosa 4\% (Tabel 1), sehingga kerapatan bakteri pada konsentrasi laktosa 5, 6 dan $7 \%$ lebih tinggi dibandingkan dengan pada konsentrasi $4 \%$ dan potensial yang dihasilkan lebih kecil. Jumlah bakteri yang ada pada konsentrasi laktosa $3 \%$ lebih sedikit dibandingkan dengan konsentrasi laktosa $4 \%$, sehingga elektron hasil metabolisme bakteri juga lebih sedikit yang melakukan kontak dengan elektroda. Semakin sedikit jumlah elektron yang melakukan kontak dengan elektroda maka akan semakin kecil potensial yang dihasilkan.

\section{Penentuan $\mathrm{E}_{\text {Laktosa }}^{\circ}$ pada sistem MFC}

Secara teoritis, nilai potensial sel dari sistem MFC dapat ditentukan dengan menggunakan persamaan Nernst. Nilai potensial sel tersebut bergantung pada nilai $\mathrm{E}_{\text {katoda dan }}^{\circ} \mathrm{E}_{\text {anoda, di mana }}^{\circ} \mathrm{E}_{\text {katoda }}$ merupakan nilai dari potensial sel standar pada reaksi pada reaksi katoda dan $\mathrm{E}^{\circ}$ anoda merupakan nilai dari potensial sel standar laktosa

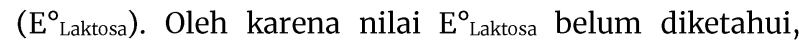
sehingga perlu ditentukan nilai $\mathrm{E}_{\text {Laktosa menggunakan }}^{\circ}$ persamaan Nerst, dengan cara mengukur potensial sel MFC yang dihasilkan sebagai $E_{s e l}$ dan mengukur konsentrasi laktosa untuk menentukan nilai Q.

$$
\mathrm{Q}=\frac{1}{\left[\mathrm{C}_{12} \mathrm{H}_{22} \mathrm{O}_{11}\right]}
$$

Dari nilai $Q$ tersebut dapat ditentukan nilai potensial sel laktosa dengan menggunakan persamaan Nernst sebagai berikut:

$$
\begin{gathered}
E=E^{\circ}-\frac{R T}{n F} \ln Q \\
E=E^{\circ}-\frac{R T}{n F} \ln \frac{1}{\left[\mathrm{C}_{12} \mathrm{H}_{22} \mathrm{O}_{11}\right]}
\end{gathered}
$$

Hubungan nilai potensial sel (hasil pengukuran) dengan konsentrasi laktosa dapat menghasilkan persamaan garis, sehingga dapat ditentukan nilai potensial sel standar laktosa.

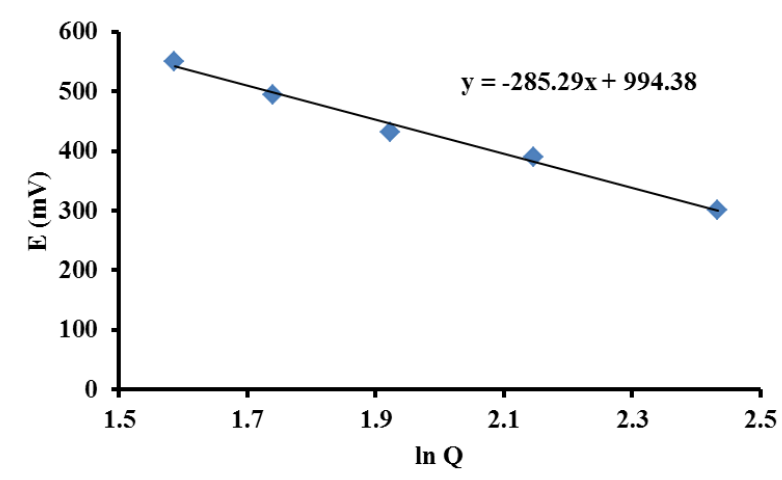

Gambar 5. Grafik hubungan potensial (E) dan $\ln Q$

Dari grafik tersebut, persamaan garis yang diperoleh diubah ke dalam persamaan Nerst sehingga dapat

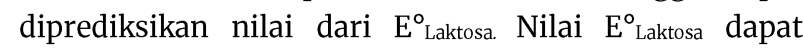
dihitung dengan persamaan sebagai berikut:

Reaksi pada MFC:

$$
\begin{aligned}
& \mathrm{C}_{12} \mathrm{H}_{22} \mathrm{O}_{11}+12 \mathrm{O}_{2} \rightarrow 12 \mathrm{CO}_{2}+11 \mathrm{H}_{2} \mathrm{O} \\
& \mathrm{E}^{0}=\mathrm{E}_{\mathrm{O}_{2} \mid \mathrm{H}_{2} \mathrm{O}}^{0}-\mathrm{E}_{\mathrm{C}_{12} \mathrm{H}_{22} \mathrm{O}_{11} \mid \mathrm{CO}_{2}}^{0}
\end{aligned}
$$

Dari persamaan tersebut diperoleh nilai $\mathrm{E}_{\text {Laktosa }}^{\circ}$ sebesar + 0,236 V. 


\section{Kesimpulan}

Konsentrasi laktosa sebagai substrat Lactobacillus bulgaricus pada sistem MFC dapat berpengaruh pada potensial sel yang dihasilkan. Potensial sel maksimum yang dihasilkan dari sistem MFC adalah pada konsentrasi laktosa $4 \%$ sebesar $710 \mathrm{mV}$. Nilai $\mathrm{E}_{\text {Laktosa yang diperoleh }}^{\circ}$ pada sistem MFC sebesar $+0,236 \mathrm{~V}$.

\section{Daftar Pustaka}

[1] Enas Taha Sayed, Takuya Tsujiguchi, Nobuyoshi Nakagawa, Catalytic activity of baker's yeast in a mediatorless microbial fuel cell, Bioelectrochemistry, 86, (2012) 97-101 https://doi.org/10.1016/j.bioelechem.2012.02.001

[2] Nor Sri Inayati, Agustina L. N. Aminin, Linda Suyati, The Bioelectricity of Tofu Whey in Microbial Fuel Cell System with Lactobacillus bulgaricus, Jurnal Sains dan Matematika, 23, 1, (2015) 32-38

[3] Dini Noor Hayati, Rahmad Nuryanto, Linda Suyati, Effect of Series Circuit on the Lactose Bioelectricity of a Microbial Fuel Cell System using Lactobacillus bulgaricus, Jurnal Sains dan Matematika, 23, 3, (2015) 84-89

[4] D'souza Rohan, Verma Deepa, Gavankar Rohan, Bhalerao Satish, Bioelectricity Production from Microbial Fuel using Escherichia Coli (Glucose and Brewery Waste), International Research Journal of Biological Sciences, 2, 7, (2013) 50-54

[5] P. Teixeira, H. Castro, C. Mohácsi-Farkas, R. Kirby, Identification of sites of injury in Lactobacillus bulgaricus during heat stress, Journal of Applied Microbiology, $\quad 83, \quad 2, \quad$ (1997) 219-226 http://dx.doi.org/doi:10.1046/j.13652672.1997.00221.x

[6] C. Siu, M. Chiao, A Microfabricated PDMS Microbial Fuel Cell, Journal of Microelectromechanical Systems, $17, \quad 6, \quad$ (2008) 1329-1341 10.1109/JMEMS.2008.2006816

[7] Seung Won Lee, Bo Young Jeon, Doo Hyun Park, Effect of bacterial cell size on electricity generation in a single-compartmented microbial fuel cell, Biotechnology Letters, 32, 4, (2010) 483-487 http://dx.doi.org/10.1007/s10529-009-0184-1 